Since many of the sera tested were from ill children these results might not give a true picture of the prevalence of antibody. Sera from a group of healthy primary schoolchildren were therefore examined and, as shown in table II, the incidence of antibody in this group was of a similar order.

The highest incidence of antibody to B.K. virus occurred between the ages of 6 and 17 years. It is also in this age range that the proportion of sera with high H.I. titres of 2,560 or greater were found (table II). The highest C.F. titres were observed in the age group 1-10 years. These findings suggest that the virus is actively transmitted throughout the period of childhood.

In an attempt to associate infection with some clinical condition a small number of paired sera were examined. These were obtained from children suffering from a wide range of undiagnosed illnesses of a possible viral aetiology. No seroconversions or fourfold increase in titres were found (table III), and the distribution of antibody was similar to that in other groups.

TABLE III-Haemagglutination-inhibition Antibody to B.K. Virus in Paired Sera from Children

\begin{tabular}{c|c|c|c|c}
\hline Age & $\begin{array}{c}\text { No. of Paired } \\
\text { Sera } \\
\text { Examined }\end{array}$ & $\begin{array}{c}\text { No. of Paired } \\
\text { Sera with } \\
\text { Antibody }\end{array}$ & $\begin{array}{c}\text { Range of } \\
\text { Titres }\end{array}$ & $\begin{array}{c}\text { No. of Paired } \\
\text { Sera Showing } \\
\text { a Sero- } \\
\text { conversion or } \\
\text { Fourfold Rise } \\
\text { in Titre }\end{array}$ \\
\hline $\begin{array}{c}6-11 \text { months } \\
1-5 \text { years } . .\end{array}$ & 18 & 0 & -5 \\
$6-9$ ".. & 10 & 9 & $\begin{array}{c}640-20,480 \\
80-10,240\end{array}$ & 0 \\
\hline
\end{tabular}

\section{Discussion}

It has been known for some time that polyoma-like viruses may exist in man. ZuRhein and Chou (1965) described particles, morphologically identical with polyomaviruses, which they observed in brain cells in a rare neurological disease-progressive multifocal leucoencephalopathy.

All attempts to culture this virus were unsuccessful until, by using human fetal glial cells, Padgett et al. (1971) reported the isolation of a virus (J.C.) from a brain extract of a patient with progressive multifocal leucoencephalopathy. This virus appeared to be unrelated to the mouse polyomavirus and simian virus $\mathbf{4 0}$ $\left(\mathrm{SV}_{40}\right)$. The frequency of antibody to this J.C. virus in the general population has not been described.

Further virus isolations from two additional cases of progressive multifocal leucoencephalopathy have been reported (Weiner et al., 1972). In these cases the viruses isolated were thought to be identical with $\mathrm{SV}_{40}$.

Antibody to $\mathrm{SV}_{40}$ virus has been found in sera from persons who received contaminated poliovaccine or who had contact with monkeys, both known sources of this virus. It has also been found in persons not in these categories (Shah, 1972). However, the number of persons with antibody has been found to be small and the titres low. This suggested that if another source of $\mathrm{SV}_{40}$ exists or if there is an antigenically identical human virus, infection is not common. Shah et al. (1971) suggested the possibility that the antibody detected in these persons might be the result of a cross-reaction with another member of the polyoma-SV 40 group of viruses.

With the report of the isolation of the polyoma-like virus (B.K.) from the urine of an immunosuppressed patient it was evident that infection can occur in man without involving the central nervous system. In this patient virus particles were found by electron microscopy in infected ureteric cells as well as in the urine (Gardner et al., 1971). The presence of antibody before the renal transplant in both patient and donor suggested that the virus could be common in man and with immunosuppressive therapy could become activated.

The serological results presented in this paper indicate that infection with B.K. virus is indeed widespread. However, no clinical illness has so far been associated with the infection nor is it known yet how the virus is transmitted.

\section{References}

Gardner, S. D., Field, A. M., Coleman, D. V., and Hulme, B. (1971). Lancet, 1, 1253.

Padgett, B. L., Walker, D. L., ZuRhein, G. M., and Eckroade, R. J. (1971) Lancet, $1,1257$.

Shah, K. V. (1972). American fournal of Epidemiology, 95, 199.

Shah, K. V., Ozer, H. L., Pond, H. S., Palma, L. D., and Murphy, G. P. (1971). Nature, 231, 448.

Weiner, L. P. et al. (1972). New England fournal of Medicine, 286, 385.

ZuRhein, G. M., and Chou, Shi-Ming (1965). Science, 148, 1477.

\title{
Oxygen Transport in Acute Pulmonary Oedema and in Acute Exacerbations of Chronic Bronchitis
}

\author{
D. C. FLENLEY, H. C. MILLER, A. J. KING, B. J. KIRBY, A. L. MUIR
}

British Medical fournal, 1973, 1, 78-81

\section{Summary}

When breathing air, the average arterial oxygen tension in eight patients with acute pulmonary oedema was significantly higher than in eight other patients suffering from an acute exacerbation of chronic bronchitis, but the mixed venous oxygen tension was very similar in both groups. This largely arose from the smaller arterio-

\footnotetext{
University of Edinburgh, Department of Medicine, Royal Infirmary, Edinburgh EH3 9YW

D. C. FLENLEY, M.B., F.R.C.P., Senior Lecturer and Honorary Consultant Physician

H. C. MILLER, M.B., M.R.C.P., Research Fellow (Present address: Cardiac Department, Brompton Hospital, London S.W.3)

A. J. KING, M.B., M.R.C.P., Lecturer (Present address: St. James's Hospital, Leeds LS9 7TF)

B. J. KIRBY, M.B., M.R.C.P., Lecturer

A. L. MUIR, M.D., M.R.C.P., Lecturer
}

venous difference of oxygen content in the bronchitic cases, presumably due to their higher cardiac output, associated with raised arterial $\mathrm{CO}_{2}$ tensions. Oxygen therapy $(60-90 \%$ for pulmonary oedema, $30 \%$ for the bronchitics) raised the mixed venous oxygen tensions to a similar level in both groups. We suggest that the major need for oxygen therapy lies in patients who maintain their oxygen consumption but show a reduction in mixed venous tension when breathing air. Although partial correction of arterial hypoxaemia is adequate in chronic bronchitis-in which the cardiac output is maintained-high concentrations of oxygen are necessary in pulmonary oedema, in which the cardiac output is low.

\section{Introduction}

Most agree that hypoxia should be corrected in both acute and pulmonary oedema and in acute exacerbations of chronic bron- 
chitis, yet debate continues on the precise indications for oxygen therapy and on the levels of oxygen tension $\left(\mathrm{Po}_{2}\right)$ to be aimed at in treating these patients (Campbell, 1960; Hutchison, et al., 1964; Eldridge, 1966; McNicol, 1967; Sykes et al., 1969; Flenley, 1970; Macklem, 1971; Suiger and Hamilton, 1971). A rational approach to oxygen therapy might consider delivery of oxygen to its site of usage in the cellular mitochondria, transfer to this site from the adjacent capillaries depending on diffusion down a pressure gradient (Flenley, 1967). Such an analysis emphasizes the importance of an adequate capillary $\mathrm{Po}_{2}$, which in turn depends on the $\mathrm{Po}_{2}$ at both arterial and venous ends of the capillary. In seeking to rationalize our treatment of these hypoxaemic patients we have compared oxygen transport in terms of arterial $\left(\mathrm{PaO}_{2}\right)$ and mixed venous $\left(\mathrm{Pv}_{2}\right)$ oxygen tensions in eight patients with acute pulmonary oedema and in another eight patients suffering from an acute exacerbation of respiratory failure due to chronic bronchitis and emphysema, using simple methods suitable for the bedside investigation and management of such seriously ill patients.

\section{Patients and Methods}

We diagnosed pulmonary oedema in cases 1 to 8 from (a) their history of acute dyspnoea, cough, and frothy sputum; (b) bilateral basal crepitations and a third heart sound; and (c) chest $x$-ray appearances (table I). Acute myocardial infarction occurring up to 24-72 hours earlier was diagnosed by the history and serial E.C.G.s in cases 1 to 6 and confirmed by a subsequent rise in serum enzymes. We diagnosed an acute exacerbation of chronic bronchitis and emphysema in cases 9 to 16 from (a) persistent dyspnoea with recent cough and purulent sputum; (b) chest hyperinflation; $(c)$ the absence of other abnormalities on a chest $x$-ray picture; and $(d)$ a persistently low forced expiratory volume in one second/forced vital capacity $\left(F E V_{1} / F V C\right)$ ratio. Cases 2,3 , and 8 died between two and 14 days after the study from intractable heart failure, and cases 12 and 16 died from respiratory failure seven and 10 days later.

The patients or their relatives had consented to the study after explanation of its nature and purpose. Though we sought information to indicate the correct treatment it was emphasized that these studies were not essential to their conventional management.

Within two to 72 hours of admission to hospital due to their acute illness a nylon catheter $(1.2 \mathrm{~mm}$ outside diameter) was inserted percutaneously into the left radial or brachial artery (Berneus et al., 1954) and a polyethylene catheter $(0.75 \mathrm{~mm}$ outside diameter) into an antecubital vein, this catheter being "floated" into the pulmonary artery (Bradley, 1964), as shown by the pressure waveform. The patient lay in bed at about $45^{\circ}$, with E.C.G. monitoring throughout the study. Parenteral drug therapy (heroin and digoxin in cases 1 to 8 , antibiotics and digoxin in cases 9 to 16) was given up to one hour before the study, as clinically indicated, but no intravenous diuretics had been given for the previous four hours.

We drew simultaneous anaerobic blood samples over five minutes from both systemic and pulmonary arterial catheters into heparinized syringes, for measurement of oxygen capacity (King and Wootton, 1956) and of $\mathrm{Po}_{2}, \mathrm{PcO}_{2}$, and $\mathrm{pH}$ by Instrumentation Laboratories type 113 electrodes calibrated with gas mixtures and tonometered blood (Flenley et al., 1967). Blood oxygen content was calculated from $\mathrm{Po}_{2}, \mathrm{pH}$ (Severinghaus, 1966), and oxygen capacity measurements, without correction for any changes in dissociation curves arising from variation in 2:3 diphosphoglycerate levels (Bellingham et al., 1971). We took samples when the patients were breathing air and then oxygen (60-90\% in cases 1 to $8,30 \%$ in cases 9 to 16$)$, both for at least 20 minutes beforehand.

\section{Results}

Breathing Air. Arterial hypoxaemia was more pronounced in the bronchitic patients (cases 9 to 16 ) (mean $\mathrm{PaO}_{2}$ 44.8, S.D. $11.7 \mathrm{~mm} \mathrm{Hg}$ ) than in the patients with pulmonary oedema (cases 1 to 8), where the mean $\mathrm{PaO}_{2}$ was 55.5 (S.D. 13.4) $\mathrm{mm} \mathrm{Hg}$. The mean $\mathrm{P}_{\mathrm{v} \mathrm{O}_{2}}$, however, was almost identical in the two groups, being 26.3 (S.D. 4.7) $\mathrm{mm} \mathrm{Hg}$ in cases 1 to 8 and 27.9 (S.D. 5.6) $\mathrm{mm} \mathrm{Hg}$ in the bronchitic patients (cases 9 to 16) fig. 1, table II). Five of the cases with pulmonary oedema had a respiratory alkalosis with a low $\mathrm{PaCO}_{2}$, one (case 3) a metabolic

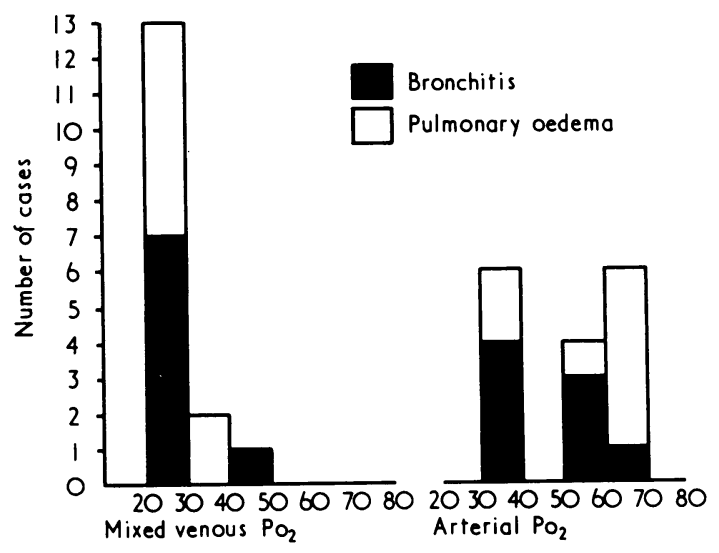

FIG. 1-Frequency histogram of arterial and mixed venous $\mathrm{Po}_{2}$ in cases 1 to 8 with pulmonary oedema, and in cases 9 to 16 (with chronic bronchitis) when breathing air.

TABLE I-Clinical Details of Patients

\begin{tabular}{|c|c|c|c|c|c|c|c|c|c|c|}
\hline $\begin{array}{l}\text { Case } \\
\text { No. }\end{array}$ & $\begin{array}{c}\text { Age } \\
\text { in } \\
\text { Years }\end{array}$ & Sex & History & $\begin{array}{c}\text { Blood } \\
\text { Pressure } \\
(\mathrm{mm} \mathrm{Hg})\end{array}$ & $\begin{array}{l}\text { Blood Urea } \\
(\mathrm{mg} / 100 \mathrm{ml})\end{array}$ & $\underset{(\mathrm{g} / 100 \mathrm{ml})}{\text { Haemoglobin }}$ & E.C.G. & $\begin{array}{l}\text { Chest } \\
X \text {-ray }\end{array}$ & $\underset{\text { (litres) }}{\text { FEV }_{1}}$ & $\begin{array}{c}\text { FVC } \\
\text { (litres) }\end{array}$ \\
\hline \multicolumn{11}{|c|}{ Pulmonary oedema } \\
\hline $\begin{array}{l}1 \\
2 \\
3 \\
4 \\
5 \\
6 \\
7 \\
8\end{array}$ & $\begin{array}{l}64 \\
64 \\
69 \\
44 \\
63 \\
67 \\
72 \\
70\end{array}$ & $\begin{array}{l}\text { M. } \\
M \\
M \\
M \\
M . \\
\text { M. } \\
\text { F. } \\
\text { M. }\end{array}$ & $\begin{array}{l}\text { C.P., B., } 3 \text { days } \\
\text { B., } 12 \mathrm{hr} \\
\text { B., } 4 \text { hr, C.P., } 2 \text { days } \\
\text { C.P., B., } 12 \mathrm{hr} \\
\text { C.P., B., } 2 \text { days } \\
\text { B., } 7 \text { days } \\
\text { B., } 2 \text { days } \\
\text { C.P., } 2 \text { days }\end{array}$ & $\begin{array}{l}140 / 90 \\
115 / 60 \\
100 / 60 \\
120 / 75 \\
120 / 70 \\
130 / 50 \\
120 / 60 \\
140 / 70\end{array}$ & $\begin{array}{r}108 \\
39 \\
72 \\
35 \\
42 \\
53 \\
80 \\
54\end{array}$ & $\begin{array}{l}15 \cdot 5 \\
15 \cdot 9 \\
15 \cdot 7 \\
15 \cdot 0 \\
14 \cdot 7 \\
12 \cdot 5 \\
11 \cdot 8 \\
16 \cdot 8\end{array}$ & $\begin{array}{l}\text { A.M.I. } \\
\text { A.M.I. } \\
\text { A.M.I. } \\
\text { A.M.I. } \\
\text { A.M.I. } \\
\text { A.F. } \\
\text { L.V.H. } \\
\text { A.M.I. }\end{array}$ & $\begin{array}{l}\text { III } \\
\text { II } \\
\text { I } \\
\text { I } \\
\text { I } \\
\text { I } \\
\text { II } \\
\text { II }\end{array}$ & $\begin{array}{l}0.8 \\
1.5 \\
0.9 \\
0.8 \\
0.9 \\
0.7 \\
-\end{array}$ & $\begin{array}{l}2 \cdot 1 \\
2.4 \\
1.4 \\
\frac{1}{1.4} \\
1.4 \\
1.3 \\
-\end{array}$ \\
\hline \multicolumn{11}{|c|}{ Chronic bronchitis } \\
\hline $\begin{array}{l}9 \\
0 \\
1 \\
2 \\
3 \\
4 \\
15 \\
6\end{array}$ & $\begin{array}{l}59 \\
56 \\
58 \\
68 \\
70 \\
68 \\
58 \\
63\end{array}$ & $\begin{array}{l}\text { M. } \\
\text { M. } \\
\text { M. } \\
\text { F. } \\
\text { M. } \\
\text { M. }\end{array}$ & $\begin{array}{l}\text { B., C.S., } 10 \text { years } \\
\text { B., C.S., } 20 \text { years } \\
\text { B., C.S., } 20 \text { years } \\
\text { B., C.S., } 10 \text { years } \\
\text { B., C.S., } 20 \text { years } \\
\text { C.P., 14 days; B., C.S., } 3 \text { years } \\
\text { C.P., 7 days; B.,C.S., } 10 \text { years } \\
\text { B., C.S., } 20 \text { years }\end{array}$ & $\begin{array}{l}200 / 85 \\
125 / 60 \\
140 / 60 \\
145 / 60 \\
150 / 75 \\
125 / 70 \\
155 / 75\end{array}$ & $\begin{array}{r}75 \\
26 \\
43 \\
54 \\
48 \\
145 \\
64 \\
40\end{array}$ & $\begin{array}{l}13 \cdot 6 \\
14 \cdot 1 \\
16 \cdot 1 \\
10 \cdot 5 \\
13 \cdot 6 \\
12 \cdot 3 \\
14 \cdot 3 \\
13 \cdot 4\end{array}$ & $\begin{array}{l}\text { R.ज. } \\
\text { R.V.H. } \\
\text { O.M.I. } \\
\text { N. } \\
\text { N. } \\
\text { N. } \\
\text { N. }\end{array}$ & & $\begin{array}{l}0.5 \\
0.4 \\
0.3 \\
0.3 \\
0.4 \\
0.3 \\
0.5 \\
0.3\end{array}$ & $\begin{array}{l}0.9 \\
0.9 \\
0.8 \\
0.8 \\
1.0 \\
1.0 \\
1.2 \\
0.7\end{array}$ \\
\hline
\end{tabular}

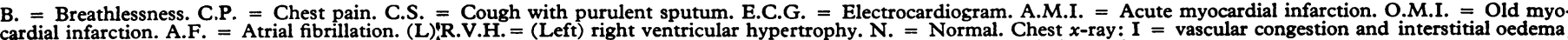
cardial infarction. A.F. $=$ Atrial fibrillation. (L) R.V.H. $=$ (Left) right ventricular hypertrophy. N. $=$ Normal. Chest $x$-ray: I $=$ alveolar oedema; III = confluent opacities. FEV $=$ Forced expiratory volume in 1 sec. FVC $=$ Forced vital capacity. 
TABLE II-Arterial and Mixed Venous Blood Gas Tensions and pH

\begin{tabular}{|c|c|c|c|c|c|c|c|c|c|c|c|c|c|c|}
\hline \multirow{3}{*}{$\begin{array}{l}\text { Case } \\
\text { No. }\end{array}$} & \multicolumn{7}{|c|}{ Breathing Air } & \multicolumn{7}{|c|}{ Breathing Oxygen } \\
\hline & \multicolumn{3}{|c|}{ Arterial } & \multicolumn{3}{|c|}{ Mixed Venous } & \multirow{2}{*}{$\begin{array}{c}\text { Arteriovenous } \\
\text { Difference in } \\
\text { Oxygen Content } \\
(\mathrm{ml} / 100 \mathrm{ml}) \\
\end{array}$} & \multicolumn{3}{|c|}{ Arterial } & \multicolumn{3}{|c|}{ Mixed Venous } & \multirow{2}{*}{$\begin{array}{l}\text { Arteriovenous } \\
\text { Difference in } \\
\text { Oxygen Content } \\
(\mathrm{ml} / 100 \mathrm{ml})\end{array}$} \\
\hline & $\begin{array}{c}\mathrm{Po}_{2} \\
(\mathrm{~mm} \mathrm{Hg})\end{array}$ & $\begin{array}{c}\mathrm{PCO}_{2} \\
(\mathrm{~mm} \mathrm{Hg})\end{array}$ & $\mathrm{pH}$ & $\begin{array}{c}\mathrm{Po}_{2} \\
(\mathrm{~mm} \mathrm{Hg})\end{array}$ & $\begin{array}{c}\mathrm{PCO}_{2} \\
(\mathrm{~mm} \mathrm{Hg})\end{array}$ & $\mathrm{pH}$ & & $\begin{array}{c}\mathrm{Po}_{2} \\
\left(\mathrm{~mm} \mathrm{Hg}^{2}\right)\end{array}$ & $\begin{array}{c}\mathrm{PcO}_{2} \\
(\mathrm{~mm} \mathrm{Hg}) \\
\end{array}$ & $\mathrm{pH}$ & $\begin{array}{c}\mathrm{Po}_{2} \\
(\mathrm{~mm} \mathrm{Hg}) \\
\end{array}$ & $\begin{array}{c}\mathrm{PcO}_{2} \\
(\mathrm{~mm} \mathrm{Hg}) \\
\end{array}$ & $\mathrm{pH}$ & \\
\hline \multicolumn{15}{|c|}{ Pulmonary oedema } \\
\hline \begin{tabular}{c|}
1 \\
2 \\
3 \\
4 \\
5 \\
6 \\
7 \\
8 \\
Mean \\
S.D.
\end{tabular} & $\begin{array}{l}39 \\
60 \\
69 \\
56 \\
62 \\
62 \\
31 \\
65 \\
55 \cdot 5 \\
13 \cdot 4\end{array}$ & $\begin{array}{l}32 \\
27 \\
28 \\
37 \\
32 \\
38 \\
28 \\
32 \\
31 \cdot 8 \\
4 \cdot 10\end{array}$ & $\begin{array}{l}7.46 \\
7.62 \\
7.35 \\
7.42 \\
7.51 \\
7.42 \\
7.53 \\
7.49 \\
7.48 \\
0.08\end{array}$ & $\begin{array}{l}22 \\
26 \\
25 \\
26 \\
31 \\
35 \\
21 \\
24 \\
26 \cdot 3 \\
4 \cdot 65\end{array}$ & $\begin{array}{l}38 \\
32 \\
37 \\
46 \\
36 \\
42 \\
36 \\
39 \\
38 \cdot 3 \\
4 \cdot 23\end{array}$ & $\begin{array}{l}7 \cdot 42 \\
7 \cdot 56 \\
7 \cdot 28 \\
7 \cdot 40 \\
7 \cdot 44 \\
7 \cdot 40 \\
7 \cdot 47 \\
7 \cdot 45 \\
7 \cdot 43 \\
0 \cdot 08\end{array}$ & $\begin{array}{c}7 \cdot 7 \\
7.7 \\
10 \cdot 6 \\
8 \cdot 5 \\
6 \cdot 5 \\
4 \cdot 3 \\
5 \cdot 0 \\
8 \cdot 5 \\
7 \cdot 35 \\
2 \cdot 04\end{array}$ & $\begin{array}{c}49 \\
425 \\
472 \\
523 \\
151 \\
54 \\
350 \\
288 \cdot 4 \\
201 \cdot 6\end{array}$ & $\begin{array}{l}39 \\
42 \\
33 \\
36 \\
42 \\
32 \\
26 \\
35 \cdot 7 \\
5 \cdot 85\end{array}$ & $\begin{array}{l}7.41 \\
7 \cdot 47 \\
7.34 \\
7.47 \\
7 \cdot 41 \\
7.49 \\
7.46 \\
7.44 \\
0.05\end{array}$ & $\begin{array}{l}28 \\
37 \\
39 \\
36 \\
44 \\
\frac{30}{35 \cdot 7} \\
5 \cdot 89\end{array}$ & $\begin{array}{l}43 \\
47 \\
41 \\
41 \\
46 \\
\frac{40}{43 \cdot 0} \\
2 \cdot 90\end{array}$ & $\begin{array}{l}7 \cdot 36 \\
7 \cdot 43 \\
7 \cdot 27 \\
7 \cdot 42 \\
7 \cdot 38 \\
7 \cdot 42 \\
7 \cdot 38 \\
0.06\end{array}$ & $\begin{array}{l}7 \cdot 1 \\
5 \cdot 7 \\
6 \cdot 7 \\
7 \cdot 0 \\
3 \cdot 5 \\
5 \cdot 0 \\
\frac{5 \cdot 83}{1 \cdot 41}\end{array}$ \\
\hline \multicolumn{15}{|c|}{ Chronic bronchitis } \\
\hline $\begin{array}{l}9 \\
10 \\
11 \\
12 \\
13 \\
14 \\
15 \\
16 \\
\text { Mean } \\
\text { S.D. }\end{array}$ & $\begin{array}{l}30 \\
33 \\
35 \\
53 \\
39 \\
54 \\
60 \\
54 \\
44 \cdot 8 \\
11 \cdot 7\end{array}$ & $\begin{array}{l}70 \\
84 \\
80 \\
67 \\
61 \\
42 \\
39 \\
40 \\
60 \cdot 4 \\
18 \cdot 09\end{array}$ & $\begin{array}{l}7 \cdot 33 \\
7 \cdot 34 \\
7 \cdot 32 \\
7 \cdot 40 \\
7 \cdot 38 \\
7 \cdot 47 \\
7 \cdot 36 \\
7 \cdot 42 \\
7 \cdot 38 \\
0 \cdot 05\end{array}$ & $\begin{array}{l}22 \\
27 \\
25 \\
28 \\
27 \\
27 \\
41 \\
26 \\
27 \cdot 9 \\
5 \cdot 62\end{array}$ & $\begin{array}{l}72 \\
87 \\
71 \\
63 \\
49 \\
46 \\
46 \\
62 \cdot 0 \\
15 \cdot 75\end{array}$ & $\begin{array}{l}7.30 \\
7.32 \\
7.31 \\
7.38 \\
7.37 \\
7.43 \\
7.30 \\
7.39 \\
7.35 \\
0.05\end{array}$ & $\begin{array}{l}3 \cdot 6 \\
2 \cdot 7 \\
4 \cdot 1 \\
5 \cdot 0 \\
4 \cdot 8 \\
6 \cdot 8 \\
5 \cdot 6 \\
7 \cdot 2 \\
4 \cdot 96 \\
1 \cdot 54\end{array}$ & $\begin{array}{c}45 \\
43 \\
51 \\
64 \\
78 \\
72 \\
117 \\
74 \\
68 \cdot 0 \\
23.94\end{array}$ & $\begin{array}{l}80 \\
87 \\
93 \\
73 \\
64 \\
38 \\
46 \\
45 \\
65 \cdot 8 \\
20 \cdot 85\end{array}$ & $\begin{array}{l}7 \cdot 29 \\
7.37 \\
7 \cdot 28 \\
7.36 \\
7.37 \\
7.47 \\
7.33 \\
7.39 \\
7.36 \\
0.06\end{array}$ & $\begin{array}{l}33 \\
33 \\
34 \\
35 \\
41 \\
30 \\
50 \\
33 \\
36 \cdot 1 \\
6 \cdot 42\end{array}$ & $\begin{array}{c}83 \\
89 \\
103 \\
79 \\
67 \\
45 \\
52 \\
49 \\
70.9 \\
21 \cdot 02\end{array}$ & $\begin{array}{l}7 \cdot 20 \\
7.32 \\
7 \cdot 23 \\
7.32 \\
7 \cdot 35 \\
7.44 \\
7 \cdot 26 \\
7.35 \\
7.31 \\
0.08\end{array}$ & $\begin{array}{l}3 \cdot 6 \\
3.7 \\
4 \cdot 2 \\
3 \cdot 6 \\
4 \cdot 6 \\
6.4 \\
4 \cdot 1 \\
5 \cdot 8 \\
4.50 \\
1 \cdot 06\end{array}$ \\
\hline
\end{tabular}

acidosis (arterial blood lactate $5.2 \mathrm{mmol} / 1$, pyruvate $0 \cdot 11$ $\mathrm{mmol} / \mathrm{l}$.), and cases 4 and 6 had a normal acid base balance in their arterial blood. In contrast five of the bronchitic cases had a chronic respiratory acidosis. In cases 12,13 , and 16 acid base balance was normal (fig. 2). The arteriovenous oxygen content difference averaged 7.35 (S.D. 2.04 ) $\mathrm{ml} / 100 \mathrm{ml}$ in the pulmonary oedema cases, significantly greater than the mean of 4.96 (S.D. 1.54) $\mathrm{ml} / 100 \mathrm{ml}$ in the bronchitic cases $(P=0.02)$.

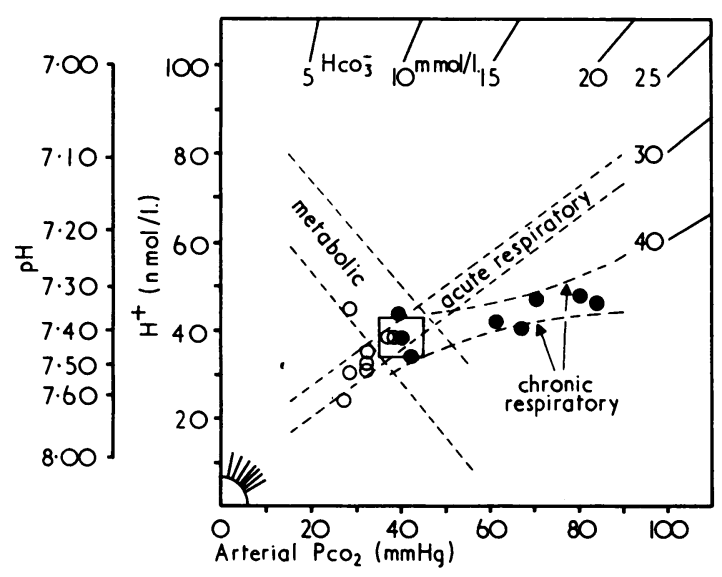

FIG. 2-Non-logarithmic acid-base diagram (Flenley, 1971) representing arterial hydrogen-ion activity $\left(\mathrm{H}^{+}\right)$, and arterial $\mathrm{PCO}_{2}$ in cases 1 to $8(\mathrm{O})$ with pulmonary oedema, and in cases 9 to $16(\%)$ with chronic bronchitis, when breathing air. Dotted lines represent $95 \%$ confidence limits for pure metabolic or respiratory acid-base disturbances (Flenley, 1971).

Breathing Oxygen (60-90\% in cases 1 to $8,30 \%$ in cases 9 to 16$)$ raised the arterial $\mathrm{Po}_{2}$ to over $100 \mathrm{~mm} \mathrm{Hg}$ in cases 2, 3, 5, 6, and 8 , but in cases 1 and 7, also with pulmonary oedema, these high concentrations of oxygen only raised the arterial $\mathrm{Po}_{2}$ to 49 and $54 \mathrm{~mm} \mathrm{Hg}$. In the bronchitic cases (9 to 16) $30 \%$ oxygen raised the arterial $\mathrm{Po}_{2}$ to $43-117 \mathrm{~mm} \mathrm{Hg}$, yet the $\mathrm{Pro}_{2}$ then rose to $30-41$ (mean $36 \cdot 1$, S.D. 6.4 ) $\mathrm{mm} \mathrm{Hg}$, very similar to the average of 35.7 (S.D. 5.9) $\mathrm{mm} \mathrm{Hg}$ achieved by the much higher inspired concentrations given to the six pulmonary oedema patients in whom we made the measurements. The arteriovenous oxygen content difference did not change significantly in either group with oxygen administration. Even this controlled oxygen therapy caused the arterial $\mathrm{PCO}_{2}$ to rise in the bronchitic cases with severe $\mathrm{CO}_{2}$ retention, in case 11 from 80 to $93 \mathrm{~mm} \mathrm{Hg}$, the arterial $\mathrm{pH}$ then falling from $7 \cdot 32$ to $7 \cdot 28$.

\section{Discussion}

The similarity of $\mathrm{Pvo}_{2}$ in these cases when breathing air, despite the differences in $\mathrm{PaO}_{2}$, arises from the wider arteriovenous oxygen content differences in the patients with pulmonary oedema, as compared to the bronchitic cases. This arteriovenous difference tended to be lower in the bronchitic cases with a high arterial $\mathrm{PCO}_{2}$, but though there was a wide variation among the cases of pulmonary oedema the arteriovenous difference was usually higher than normal, particularly in those cases with low $\mathrm{PCO}_{2}$ values (fig. 3). This distinction in arteriovenous differences, of course, largely results from the differences in cardiac output

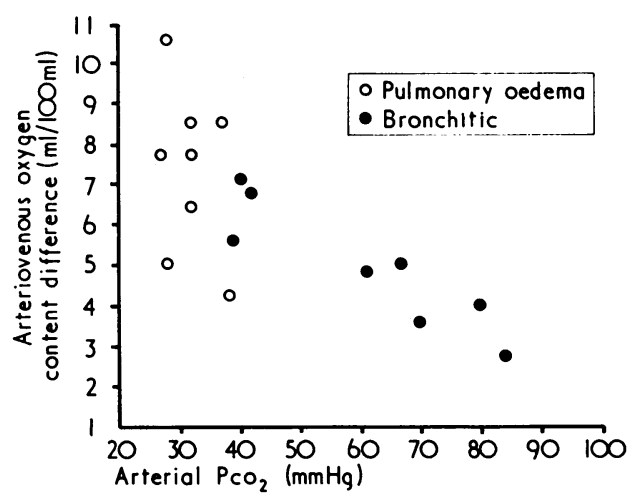

FIG. 3-Calculated arteriovenous oxygen content differences, as a function of arterial $\mathrm{PCO}_{2}$, when breathing air.

between the two groups. Assuming that the oxygen uptake in all cases was $150 \mathrm{ml} / \mathrm{min} / \mathrm{m}^{2}$ (Baldwin et al., 1948), the Fick equation shows that the cardiac index ranged from 1.4 to 3.6 $1 . / \mathrm{min} / \mathrm{m}^{2}$ in the present cases of pulmonary oedema and from $2 \cdot 1$ to $5.61 . / \mathrm{min} / \mathrm{m}^{2}$ in the bronchitic patients. High arteriovenous oxygen differences (Valentine et al., 1966) and low cardiac outputs (MacKenzie et al., 1964; Muir, 1970; Sjogren, 1970) in pulmonary oedema complicating acute myocardial infarction appear to result from left ventricular dysfunction, shown by a rise in the left ventricular end diastolic pressures (Hamosh and Cohn, 1971). Abraham et al. (1969) found the cardiac output to be maintained at normal levels in acute exacerbations of chronic ventilatory failure, as in such patients with chronically raised levels of arterial $\mathrm{PCO}_{2}$ (Wade and Bishop, 1962).

Almost full oxygen saturation, with $\mathrm{PaO}_{2}$ over $150 \mathrm{~mm} \mathrm{Hg}$, was achieved in five of the patients with pulmonary oedema who received $60-90 \%$ oxygen, but $\mathrm{PaO}_{2}$ was raised to a mean of only 
TABLE III-Mean Values of Indices of Oxygen Transport in Clinical Hypoxia

\begin{tabular}{|c|c|c|c|c|c|c|}
\hline Condition & No. of Cases & $\begin{array}{c}\text { Cardiac Index } \\
\left(1 . / \mathrm{min} / \mathrm{m}^{2}\right)\end{array}$ & $\underset{(\mathrm{mm} \mathrm{Hg})}{\text { Arterial Po }}$ & $\begin{array}{l}\text { Oxygen Consumption } \\
\left(1 . / \mathrm{min} / \mathrm{m}^{2}\right)\end{array}$ & $\underset{(\mathrm{mm} \mathrm{Hg})}{\text { Mixed Venous }} \mathrm{Po}_{2}$ & $\begin{array}{c}\text { Acute Mortality } \\
(\%)\end{array}$ \\
\hline 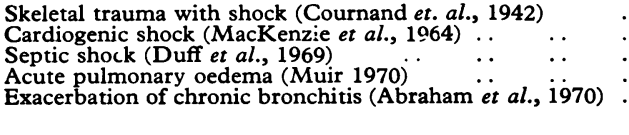 & $\begin{array}{r}4 \\
5 \\
5 \\
10 \\
8\end{array}$ & $\begin{array}{l}2.1 \\
1.7 \\
2.9 \\
2 \cdot 1 \\
3 \cdot 2\end{array}$ & $\begin{array}{l}83 \\
49 \\
57 \\
54 \\
39\end{array}$ & $\begin{array}{l}176 \\
120^{*} \\
104 \\
162 \\
120^{*} \\
160^{*}\end{array}$ & $\begin{array}{l}21 \dagger \\
22 \dagger \\
36 \dagger \\
25 \dagger \\
29 \dagger \\
27 \dagger\end{array}$ & $\begin{array}{r}0 \\
60 \\
100 \\
20 \\
0\end{array}$ \\
\hline
\end{tabular}

*Assumed values (Duff et al., 1969).

tCalculated values.

68 (S.D. 23.9) $\mathrm{mm} \mathrm{Hg}$ in the bronchitic patients who were given $30 \%$ oxygen. Nonetheless, the mean $\mathrm{P}_{\bar{v} O_{2}}$ resulting from these levels of oxygen therapy was almost indentical in both groups. We conclude that high concentrations of oxygen are not only safe but necessary in these patients when the $\mathrm{PaCO}_{2}$ is low or normal, despite their relatively high $\mathrm{PaO}_{2}$ when breathing air. Conversely, in bronchitic patients with a raised $\mathrm{PaCO}_{2}, 30 \%$ oxygen is less likely to lead to ventilatory depression (Campbell, 1960; Hutchison et al., 1964), yet still ensures adequate tissue oxygenation.

These conclusions depend on several interrelated assumptions: that $\mathrm{P}_{\mathrm{vO}} \mathrm{O}_{2}$ is a measure of tissue oxygenation; that a reduced $\mathrm{P}_{\mathrm{vO}} \mathrm{O}_{2}$ is undesirable; and that the restoration of $\mathrm{P}_{\bar{v}} \mathrm{O}_{2}$ towards normal is beneficial. Are these true? If we define the basal oxygen consumption of the body $\left(\dot{\mathrm{Vo}}_{2}\right)$ as measuring the level of energy expenditure necessary to maintain the form and function of the body at normal temperature, it follows that a reduction in $\mathrm{P} \mathrm{O}_{2}$ when at rest indicates that oxygen delivery systems are stressed. The converse does not hold, for serious reduction in oxygen delivery in one vascular bed-for example, gangrenecan be associated with vasodilatation in another, quite possibly resulting in a normal $\mathrm{PvO}_{2}$ for the whole body. But if $\mathrm{P}_{\mathrm{v}} \mathrm{O}_{2}$ is reduced, with a normal resting $\dot{\mathrm{VO}}_{2}$, oxygen transport must be in jeopardy. Permanent damage to mitochondrial enzymes (Barcroft, 1934) is presumed to arise when oxygen consumption itself starts to fall, as body oxygen stores are trivial in comparison with oxygen needs. The gap between a reduction in $\mathrm{P}_{\mathbf{v}}$ and an eventual fall in $\mathrm{VO}_{2}$ thus appears as the major field for oxygen therapy.

Measurements of both $\dot{\mathrm{V}}_{2}$ and $\mathrm{P}_{\bar{v}}{ }_{2}$ are scarce, but table III lists the mean values of cardiac output, $\mathrm{PaO}_{2}$, and either measured or assumed $\dot{\mathrm{V}}_{2}$ (Cournand et al., 1942; MacKenzie et al., 1964; Abraham et al., 1969; Duff et al., 1969; Muir, 1970) observed in various states of clinical hypoxia. We can calculate the $\mathrm{P}_{\mathrm{v}} \mathrm{O}_{2}$ from these results. The lowest level of $\mathrm{VO}_{2}$ in resting normal subjects aged 50-70 years is taken as $120 \mathrm{ml} / \mathrm{min} / \mathrm{m}^{2}$ (Duff et al., 1969). The measured $\dot{\mathrm{Vo}}_{2}$ was only below this level in five fatal cases of septic shock, despite their high $\mathrm{P}^{\mathrm{P}} \mathrm{O}_{2}$, suggesting that oxygen cannot be utilized at tissue level in septic shock (Mela et al., 1970), although circulatory oxygen transport may be relatively normal (Duff et al., 1969). In the other conditions $\mathrm{VO}_{2}$ remained normal or slightly raised despite reduction of $\mathrm{PvO}_{2}$ to between 20 and $30 \mathrm{~mm} \mathrm{Hg}$, with survival in most cases.

It is possible that a $\mathrm{Pro}_{2}$ of $20-30 \mathrm{~mm} \mathrm{Hg}$ is adequate, it being unnecessary to raise $\mathrm{PvoO}_{2}$ over $30 \mathrm{~mm} \mathrm{Hg}$ if $\dot{\mathrm{Vo}}_{2}$ is normal. After all, during maximal upright exercise in normal young men $\mathrm{P}_{\bar{v} \mathrm{O}_{2}}$ can transiently fall to about $15 \mathrm{~mm} \mathrm{Hg}$ without ill effects (Astrand et al., 1964), but then skeletal muscles with powerful anaerobic systems are taking most of the oxygen during exercise. Muscles can still contract with an effluent $\mathrm{Po}_{2}$ of below $10 \mathrm{~mm} \mathrm{Hg}$ (Donald et al., 1957; Stainsby and Otis, 1964). Nonetheless, it seems hazardous to argue that similarly low but persistent levels of $\mathrm{PO}_{2}$ in blood coming from other tissues are without danger merely because they can be sustained temporarily by skeletal muscle during exercise. The mixed venous $\mathrm{Po}_{2}$, which we have measured, is the resultant of both flows and oxygen contents of blood from the different regions of the body, which we did not measure, and further analysis of such regional oxygen transport would be valuable.

If these arguments are accepted it follows that clinical estimation of the cardiac output might join measurement of both the tension and content of oxygen in the arterial blood if oxygen therapy is to be administered rationally, or, alternatively, $\mathrm{PrO}_{2}$ could be measured directly. Part correction of arterial hypoxaemia may well be adequate if the cardiac output is normal, as in the present bronchitic patients, but more adequate correction may be required if the cardiac output is reduced, as in pulmonary oedema.

We thank Professor K. W. Donald, Drs. V. A. Kurien and C. C. Smith, and Sister A. J. McLay for advice and help. H.C.M. was supported by the Medical Research Council.

Requests for reprints should be addressed to: Dr. D. C. Flenley, Department of Medicine, Royal Infirmary, Edinburgh EH3 9YW.

\section{References}

Abraham, A. S. et al. (1969). Circulation Research, 24, 51.

Astrand, P. O., Cuddy, T. E., Saltin, B., and Stenberg, J. (1964). Fournal of Applied Physiology, 19, 268.

Baldwin, E. de F., Cournand, A., and Richards, D. W. (1948). Medicine, 27, 243 .

Barcroft, J. (1934). Features in the Architecture of Physiological Function. Cambridge, Cambridge University Press.

Bellingham, A. J., Detter, J. C., and Lenfant, C. (1971). fournal of Clinical Investigation, 50, 700 .

Berneus, B, Carlsten, A., Holmgren, A., and Seldinger, S. I. (1954). Scandinavian fournal of Clinical and Laboratory Investigation, 6, 217.

Bratley, R. D. (1964). Lancet, 2, 941.

Campbell, E. J. M. (1960). Lancet, 2, 12.

Cournand, A. et al. (1942). Surgery, 13,964.

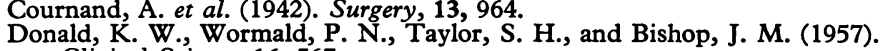
Clinical Science, 16, 567.

Duff, J. H., Groves, A. C., McLean, A. P. H., Lapointe, R., and MacLean, J. D. (1969). Surgery, Gynaecology and Obstetrics, 128, 1051.

Eldridge, F. (1966). New England fournal of Medicine, 274, 878.

Flenley, D. C. (1967). Lancet, 1, 270.

Flenley, D. C. (1970). Scottish Medical fournal, 15, 61.

Flenley, D. C. (1971). Lancet, 1, 961. Flenley, D. C., Millar, J. S., and Rees, H. A. (1967). British Medical fournal,

Hamosh, P., Cohn, J. N. (1971). Journal of Clinical Investigation, 80, 523.

Hutchison, D. C. S., Flenley, D. C., and Donald, K. W. (1964). British Medical fournal, 2, 1159.

King, E. J., and Wootton, I. D. P. (1956). Micro-analysis in Medical Biochemistry, 3rd edn,, p. 255. London, Churchill.

MacKenzie, G. J. et al. (1964). Lancet, 2, 825.

McNicol, M. W. (1967). Hospital Medicine, 1, 601

Macklem, P. T. (1971). New England Fournal of Medicine, 284, 916.

Mela, L., Bacalzo, L. V., White, R. V., and Miller, L. D. (1970). Surgical Forum, 21, 6.

Muir, A. L. (1970). M.D. Thesis, University of Edinburgh.

Severinghaus, J. W. (1966). Fournal of Applied Physiology, 21, 1108.
Sjogren, A. (1970). Acta Medica Scandinavica, Suppl. 510.

Stainsby, W. N., and Otis, A. B. (1964). American fournal of Physiology, 206, 858 . 206, 858.
Suiger, M. M., Hamilton, W. K. (1971). New England fournal of Medicine,
284, 917.

Sykes, M. K., McNicol, M. W., and Campbell, E. J. M. (1969). Respiratory Failure. Oxford, Blackwell Scientific.

Valentine, P. A. et al. (1966). Lancet, 2, 837.

Wade, O. L., and Bishop, J. M. (1962). Cardiac Output and Regional Blood Flow. Oxford, Blackweil Scientific. 